DOI: $10.20472 /$ TEC.2020.009.006

\author{
DOINA TODORUT \\ Valahia University of Targoviste, Romania \\ IONICA-LUMINIŢA MANDA (STOENICĂ) \\ Valahia University of Targoviste, Romania \\ MIHAELA DENISA COMAN
}

Institute of Multidisciplinary Research for Science and Technology - Valahia University of Targoviste, Romania

\title{
MANAGEMENT OF CRISIS SITUATIONS, ESSENTIAL CONDITION IN INCREASING THE EFFICIENCY OF THE ENTREPRENEURSHIP ACTIVITY AND IMPROVING THE WORKING CLIMATE IN SCHOOL ORGANIZATIONS
}

\begin{abstract}
:
The deployment and the pressure according to the crisis have major implications in all departments and levels of organizations regarding the responsibility and permanently in front of the employees, the service offered, influencing the efficiency of the activity of activating in the organization. Crisis management in the organization involves the manager's involvement, first of all, which is supposed to know his teaching staff very well and shows that he is involved in understanding the conflict-generating situations, ultimately determining the crisis. Also, the crisis cell, the team designated to solve the crisis comes in direct contact with the provocative elements that inevitably appear. These belong to the intervention of the press, or given by the sensitization that is felt, by the actual action of receiving the information under conditions not exactly convenient for the "actors" who play the main role in the crisis-generating conflict.
\end{abstract}

\section{Keywords:}

Crisis states; Manager; Teaching staff; Crisis cell

JEL Classification: H12, J59, M54 


\section{Introduction}

In any organization's activity, regardless of whether it is small or large, its efficiency is conditioned by the means of communication, the establishment, and cohesion of the group involved in entrepreneurship. Inevitably, conflicts also arise, which depending on the impact on the manager and the employees, can generate more profound moments, of maximum intensity, developing a crisis. Fortunately, there is specialized literature that offers the manager of the organization and not only him, a starting point in the professional management of a crisis state that manifests itself between different active participants of the organization.

The management of these conflicts, their prevention implies the knowledge of the techniques of psychological analysis of the behavior of the human resource, the ability to express persuasion and empathy towards those around, the degree of personal involvement in the personal development, in increasing the efficiency of the activity that aims to reach the objectives set in the organization, in the considerable increase of the loyalty to the organization, of the consolidation of the feeling of belonging to the group and implicitly to the organization of which those involved or present in such a crisis state.

The crisis is in connection with the presence and unfolding of a problem. In this research, attention is paid to situations that favor conflicts in the school organization. The complexity of life as a whole, of the actions of each individual that forms the society, has undergone a wide transformation in parallel with the progress of humanity in all fields of activity. The leadership of individuals takes place from the group formed in the family to the mass leadership at the organizational and national levels.

The management, as a scientific field, analyzes, argues and elaborates rules, norms, principles, connections, structures, ways and procedures of management, with the purpose of raising the degree of improvement of the system and improving the efficiency of the management action (Carstina, n.a.).

\section{Crisis situation-theoretical aspects}

There is a variety of definitions that reflect aspects of the crisis term. It is a long-debated term because the concrete events that give meaning to the crisis term bring to the force different interpretations of it. To this end, several scientific ways are meant to explain this term, and thus a multitude of epistemological features appear and a diverse range of methodologies adopted by researchers (Chiciudean, David, 2011). The term crisis - Krisis has its origins in ancient Greece. As in the present, even in those times, it had more meanings, especially since in political and normative language; it had a significance of decision or difference, of differentiation.

Thucydides is the historian, who, in the monograph of the Peloponnesian War, recalls six times the term of crisis, reflecting legal tendencies „a judgment or decision that does not result and does not rely on the existing evidence." Over time, this term also calls for a critical synthesis, a decision, meaning an action to evaluate and analyze a phenomenon. Aristotle emphasizes the two concerns that should not be missing from the citizen, namely the evaluation (crisis) and the action of driving (kratein). The meaning given in medicine of the crisis is given by the Hippocratic Treaties, that is, it represents the intensification of a suffering or a disease, very easy to observe by a spontaneous change of its state (Coman, 2009).

The crisis appears as a significant phenomenon with complex implications within the organization 
and even of human society, in each field of activity. Because there are many attempts to define the crisis and the crisis situation, there are several aspects of the research, namely: the psychological vision, the economic and political vision, the sociological vision (Tudorel, Gherghita \& Gherghita, 2006).

Psychology deepened the analysis of clinical cases, economics and politics, through the people dedicated to their study, distinguished the organizational particularities of crisis and their methods of control, and sociology was noted by identifying the group and individual behaviors in certain crises and of disaster, be they anthropogenic or natural. It has been observed that social influence causes changes in attitude and behavior. Communications in the crises, individual behavior, and collective action are under the impulse of the social element (Mihaila, 2019).

Social influence refers to „any change that the person's relation with others (individuals, groups, institutions or society as a whole) produces on their intellectual activities, on their emotions or actions" (Mihaila, 2019). In this context, it may be the most well-known manifestations of social influence, such as: social support, identification of group rules, animation manifested within the group and its characteristics, minority imprint, phenomena that determine a change at the social level, politeness and good or otherwise, an uncomfortable state. It is motivated to include in this context the adoption of an attitude other than the initial one, the use of persuasion, because the crisis requires the analysis of individual psychologists emphasize the interpersonal aspects of the phenomena by which attitudes change (Mihaila, 2019).

\section{Types of crises in school organizations}

In the school organization environment, employees tend to align with the current imposed by others to be in harmony from a social point of view. It activates its ability to decipher the attitude and behavior of others in the organizational environment, precisely to be able to make the necessary connections to carry out the specific activity of the organization. This cognitive action used by individuals who regard their membership groups as a standard, being able to make fair comparisons with other groups, as happens with teachers who have the teaching norm consisting of hours at two or three school organizations.

The human connection, the interdependence manifested between the individuals of the organization is materialized in the aspect of the conflict, because the personal evaluation takes place, the collective assessment that brings about the disagreement if there is no consensus for the evaluation. The impact of the conflict generates a tense situation. This crisis brings with it a particular way of controlling it, determined by the one who manages the crisis, which gives it a negative or positive meaning. This is also manifested in school organizations. The crisis situation should determine the manager or the one who is delegated to manage the crisis, to identify the source/causes and particularities of the conflict.

John J. Burnett (1998) stated that the stage of understanding of the word crisis is a simple, incomplete one, which makes this term used more and more, under any circumstances, without sound justification. Different definitions appear that are partial, giving a particular meaning and characteristics to events in the life of the organization. Also, the crisis can be interpreted as the unfolding of a case or a multitude of cases/events with a series of specific characteristics, which go beyond the limit of daily routine, generating states with varying degrees of uncertainly, doubt, threats which certainly affects the activity and behavior in the organization (Chiciudean, David, 2011). 


\section{Figure 1: Crises classification by different criteria's}

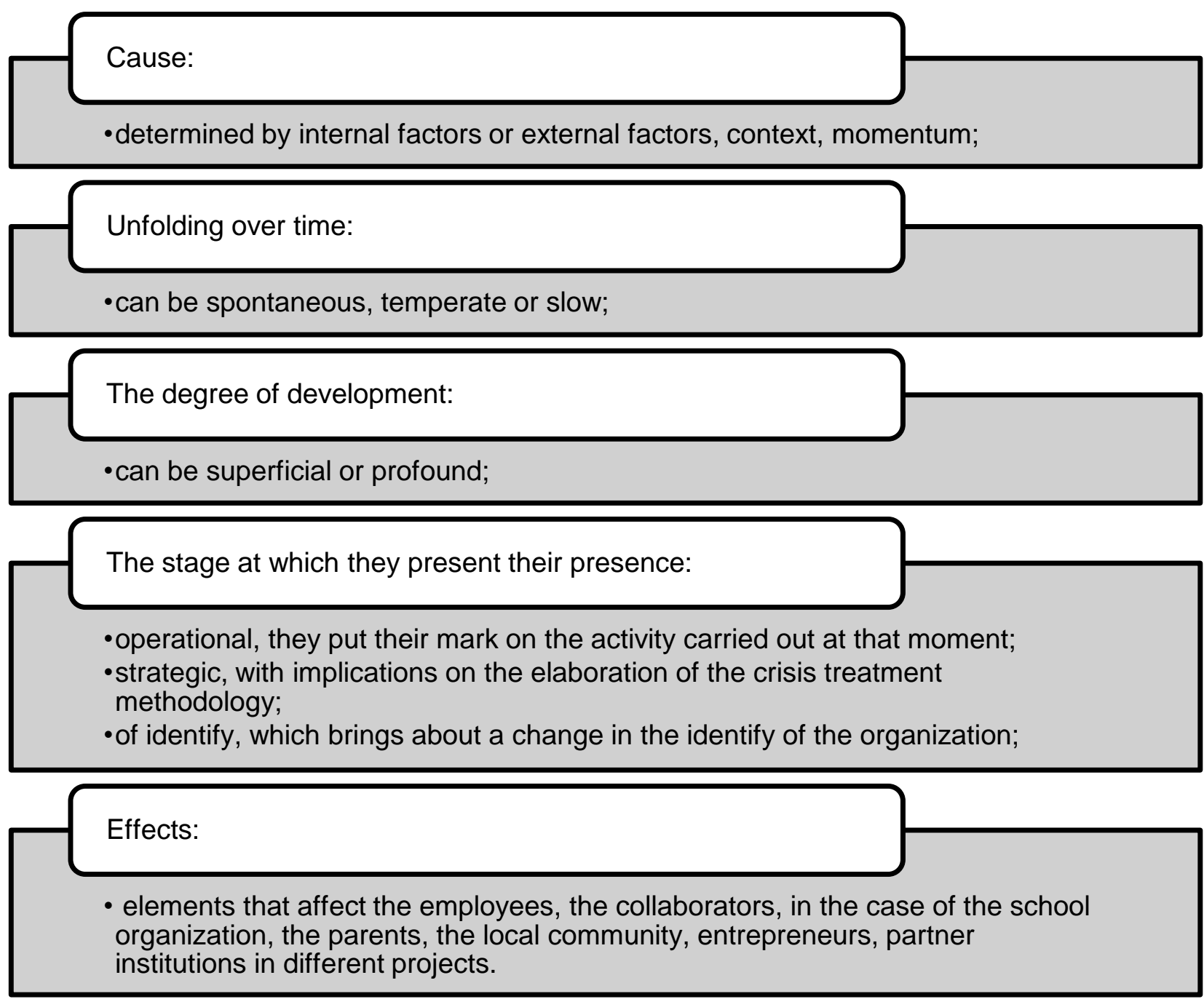

Source: Tudorel, Gherghiţa, Gherghiţa, 2006, p. 130-131.

Another classification for the types of crises was mad by J.P. Rossart, who contributed with a different classification of crises, such as internal crises and external crises.

Internal crises are characterized by certain attributes, such as the claimed attribute, which describes possible demands regarding the working mode, working conditions, salaries, job security, continuous professional development, reorganization; or the distractive attribute, such as human mistakes that result in major accidents, explosions, major damage, material and human losses.

The manifestation of external crises requires natural sources (natural disasters) or anthropogenic sources (violence, terrorism, vandalism). Crises manifestations by external sources bring major changes:

$\checkmark$ in the environment, because by the activities carried out by the human it can favor the pollution of the water, the soil, the air, the desertification, the clearing of the forest surface; 
add the destructive imprint of natural phenomena, i.e.: volcanic eruptions, storms, fires, earthquakes;

$\checkmark$ in the living standard of the employees: occupational health, safety at work, food quality;

$\checkmark$ in the state of the economy: discontent ended with strikes, bankruptcies, mergers;

$\checkmark$ in the social environment: nuclear accidents, aviation accidents, accidents on land transport, employee dissatisfaction;

$\checkmark$ in the political climate: international dissatisfaction with disagreements, changes in legislation, governments (Tudorel, Gherghita \& Gherghita, 2006).

\section{Management of crises, essential condition in increasing the efficiency of the entrepreneurship activity and improving the working climate in school organizations}

Next, we will address three conflict situations with the possibility of happening within school organizations and how to manage them, to increase the efficiency of entrepreneurship activity and to improve the working climate in school organizations.

A) The manager of the school organization radically changes his behavior towards a teacher, more precisely by blocking any means of direct communication with this teacher, not explaining to him what determined him to behave in this way. The manager is using only the transmission of messages to this teacher through the secretariat of the school organization.

Conflict mitigation and resolution of measures: in order not to further damage the atmosphere in the chancellery, but also in the classrooms, the manager must initiate specific, punctual, unambiguous discussions during a private meeting with the person in question, or within the Board of Directors; Identification of the sources generating conflict, activities undertaken, in this situation, by the teacher, expressing his intention to detect where the misunderstanding occurred; the interactivity of the communication process, resorting to bilateral feedback, possibly to mutual help.

B) Two teachers enter into a conflict that involves other teachers in the school organization. The other teachers are somewhat upset by the situation, and thus, the ambiance in the chancellery, in the classrooms can be negatively affected, with implications on the proper conduct of the instructional-educational process. Splits can be created in the unit of the teaching group and therefore measures to extinguish the conflict are required: identifying a favorable moment to initiate the communication by the manager of the school organization, or by another designated teacher or by the person in charge of the discipline commission; the initiative to communicate, using the assertive expression "I" (Stoica-Constantin, 2018). Thus the interlocutor perceives the description of the effect it has on the one who explains, helps him to understand and makes him change his attitude because he does not feel accused; the manager or the person designated to intervene in this conflict must make a series of events in order to understand the moment that favored the appearance of the conflict; encouraging the expression of the feelings and opinions of the two teachers, giving them the impression that through open communication only the parties involved will find the most appropriate solution. (Tepelea, et all, 2001).

C) Conflict state determined by the inappropriate behavior of an 8th-grade student concerning the manager of the school organization, this being his teacher in the classroom. It is a rather delicate situation, given the positions of the parties involved in the conflict. Thus, in this case, the 
efficiency of the teacher's communication capacity and his pedagogical tact are demonstrated.

As measures to remedy and resolve the conflict can be the use of active listening to promote open communication. The manager must be aware that through the position he holds he transmits, listens and retransmits (Stoica-Constantin, 2018); has the obligation to know the external causes (cultural differences, family environment, entropy, chain transmission), personality factors, especially sex differences; mental processes: shyness, nervousness, impulsivity, shock emotions; the creation by the manager of the "conflict map" including the needs, the student's shortcomings, especially since there is a different age difference and an extra level of intelligence of the parties involved; using forgiveness, because it helps the manager to focus on resolving the conflict, on identifying a fair solution for both parties, taking into account the student's feelings in school; there may have been events in the school organization or in its external environment, which induced a tense state in it.

The students cannot manage his stress (Panisoara, 2017); identifying possible solutions in an interactive dialogue. It is necessary to eliminate behaviors that inhibit, imprint a lousy character, or even block communication. Also, to reach a consensus on solutions, it is desirable to adopt a cooperative attitude. The other is seen as a partner, not as an enemy, as a hostile character. This way of vision does not force them to compromise against their interests. Still, it reflects on the action of identifying solutions (Stoica-Constantin, 2018).

\section{Conclusion}

Currently, we are facing fierce competition, and the activity of the organization is influenced to a large extent by the effects and the implications of the actions of images promotion, by ensuring optimal transparency of the range of service offered, to promote entrepreneurial activity among the young population, a solid-state that is found in the school organization.

Attracting a school population is a collective activity. It involves corroborating the efforts of the entire team of teachers, plus the contribution of the auxiliary and non-teaching staff, all under the coordination provided by the manager of the school organization, who must ensure an essential place in the list of school organizations.

The crisis is not indicated to be interpreted as a situation that allows an inappropriate attitude towards the employees. The manager must take into account the fact that human resource offers sustainability and durability to the organization. The employees gradually accept the drastic measures, being convinced that otherwise, they lose their job, but at the same time their initiative, involvement, and motivation diminish; it also reduces their performance, they will be tempted to look for another better-paying job (https://legislatiamuncii.manager.ro/a/3561/principalele-efectenegative-ale-crizei-economice-asupra-resurselor-umane.html).

\section{Acknowledgements}

This paper was co-financed from the Human Capital Operational program 2014-2020, project number POCU/380/6/13/125245 no. 36482/23.05.2019 "Excellence in interdisciplinary PhD and post-PhD research, career alternatives through entrepreneurial initiative (EXCIA)", coordinator The Bucharest University of Economic Studies". 


\section{References}

CARSTINA, D. n.a. Unele consideratii privind managementul situatiilor de criza (Some considerations regarding the management of crisis situations). Didactica Magna, No. 9. Available at: http://www.scoalarosu.ro/RO-FILES/Info pub/revista pdf/9/gest\%20situatii\%20criza.pdf accesed on 27.07.2019.

CHICIUDEAN, I., DAVID, G. (2011) Curs Managementul comunicarii in situaţii de criza (Course Communication management in crisis situations). Bucharest: Şcoala Naționala de Studii Politice și Administrative.

CHICIUDEAN, I., DAVID, G. (2011) Suport de curs Managementul comunicarii in situaţii de criza (Course support Communication management in crisis situations). Bucharest: SNSPA.

COMAN, C. (2009) Comunicarea de criza. Tehnici și strategii (Crisis communication. Techniques and strategies). lași: Polirom.

https://legislatiamuncii.manager.ro/a/3561/principalele-efecte-negative-ale-crizei-economice-asupraresurselor-umane.html, accesed on 30.08.2019.

https://legislatiamuncii.manager.ro/a/3561/principalele-efecte-negative-ale-crizei-economice-asupraresurselor-umane.html, accesed on 30.08.2019.

MIHAILA, V. (2019) Managementul comunicarii in situații de criza (Communication management in crisis situations). Bucharest: Editura Universitara.

PANISOARA, I-O. (2017) The guide of the successful teacher. laşi: Polirom Publishing House.

STOICA-CONSTANTIN, (2018) Interpersonal conflict. Prevention, resolution, and mitigation of effects. Second Edition. Iasi: Polirom Publishing House.

TEPELEA, A. Coord. şi alţii (et al) (2001) Managementul conflictului. Ghid pentru formatori şi cadre didactice (Conflict management. Guide for trainers and teachers). Buzau: Tipogrup Press.

TUDOREL, N., GHERGHITA, I., GHERGHITA, D. (2009) Comunicarea organizaționala si managementul situatiilor de criza (Organizational communication and crisis management). Bucharest: Editura Ministerului Administratiei si internelor. 